\title{
Differences in Relative Volume and Weight of Stomach Among Four Free Living Ruminants
}

\author{
J. KAMLER ${ }^{1,2}$, J. DVOŘÁK ${ }^{2}$, K. KAMLEROVÁ ${ }^{2}$
}

${ }^{1}$ Institute of Vertebrate Biology, Academy of Sciences of the Czech Republic, Brno, Czech Republic ${ }^{2}$ Mendel University of Agriculture and Forestry Brno, Faculty of Forestry and Wood Technology, Brno, Czech Republic

Received February 27, 2002

Accepted November 18, 2002

Abstract

Kamler J., J. Dvořák, K. Kamlerová: Differences in Relative Volume and Weight of Stomach Among Four Free Living Ruminants. Acta Vet. Brno 2003, 72: 33-39.

The aim of this study was to estimate similarities in relative volume and weight of stomachs of free-living red deer, fallow deer, roe deer and moufflon to evaluate their feeding strategy and probability of their interspecific competition for food sources. Studied parameters were evaluated according to season, sex, age and locality. From 1995 to 1998,176 adult (> 1 year) shot animals were examined in total. In all of the four studied species, rumen was larger in vegetation period than in winter $(p<0.01)$. The greatest differences between seasons were found in rumen volume (15-20\% on average). Differences in the volume and weight of reticulum, omasum and abomasum were smaller or not significant. The roe deer females had a higher relative volume (by $40 \%$ ) and weight (by $55 \%)$ of total stomach $(p<0.005)$ compared to males. Age of animals had no influence on size of reticulum, omasum and abomasum. The older animals had greater total stomach size. Rumen size of animals from different altitudes was the same $(p<0.05)$. The biggest relative size of total stomach and rumen was in moufflon (grazer), the smallest in roe deer (browser); fallow and red deer (both intermediate feeders) did not differ significantly. The differences between species are in agreement with their feeding strategy. Seasonal differences in rumen size correspond to the changes of their diet.

Red deer, fallow deer, roe deer, moufflon, rumen, forestomach, stomach, feeding strategies

Natural communities of ruminants are in dynamic equilibrium with their environment due to their adaptations and abundant regulatory mechanisms (predators, diseases, climatic influences). However, in an impaired environment, where certain forage sources were reduced or completely disappeared, exhaustion of attractive compounds of food supply can occur and food competition between individual species of herbivores may develop. Subsequently, these species suffer from qualitative and sometimes also quantitative lack of nutrients (e.g. Hanley 1982).

Individual ruminant species gradually adapted to usage of different compounds of food supply, and forage selectivity is considered to be the key to their adaptability to different environmental conditions (Hofmann 1989). According to the differences in size and structure of their forestomachs and their ability to utilise fibre, the ruminants can be divided into three feeding types (Hofmann 1973, 1989):

1. Browsers (concentrate selectors - CS) are focused on the best parts of food dicotyledonous plants, woody species) and have a small stomach with fast passage rate of digesta.

2. Grazers (grass and roughage eaters - GR) are able to utilise food rich in fibre (grasses) and have great stomach capacity.

3. Intermediate feeders (IM).

In natural environment, the food specialisation of individual species enables the optimal

Address for correspondence:

Ing. Jiří Kamler

Institute of Vertebrate Biology AS CR

Brno, Czech Republic
Phone: +420543422549

Fax:+420 43211346

http://www.vfu.cz/acta-vet/actavet.htm 


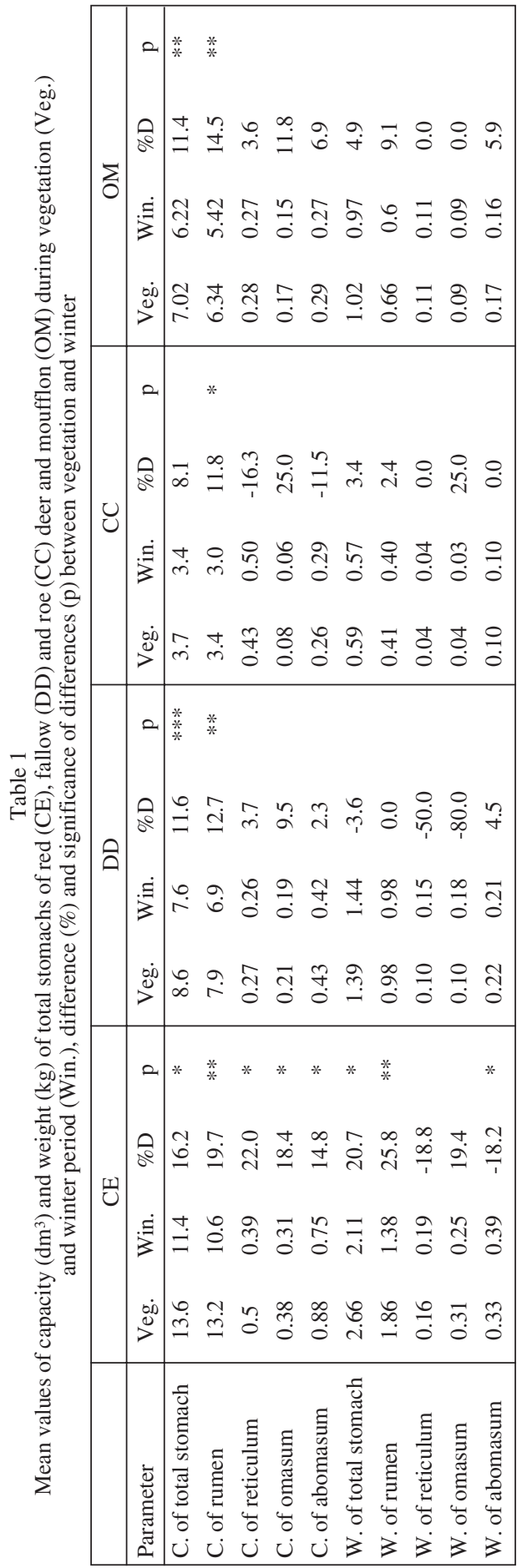

usage of all food sources and at the same time restricts the interspecific competition relations. When species that had not undergone the long-term community development are introduced into a new environment, they disturb the balanced relations and often compete with the autochthonous species. Development of food competition is then more probable between species with the same diet composition and the similar body size.

The aim of this work was to estimate similarities in food specialisation of red, fallow and roe deer and moufflon on the basis of the size of their stomachs and to evaluate probability of their interspecific competition for food sources.

Taking into account Hofmann's work (1989), we tested the hypothesis that the stomachs of red and fallow deer bear the highest similarity (both IM), while the greatest differences exist between stomachs of roe deer (CS) and moufflon (GR).

\section{Materials and Methods}

The data on digestive tract of red, fallow and roe deer and moufflon were collected from 1995 to 1998 in three localities in Moravia (mountains 800-1000 m ASL around Staré Město pod Sněžníkem and submontane landscape 250 - $350 \mathrm{~m}$ ASL around Šumperk and Brno), the Czech Republic. Localities are described in Kamler (1999)

Stomachs of 58 red deer Cervus elaphus (CE), 28 fallow deer Dama dama (DD), 65 roe deer Capreolus capreolus (CC) and 25 moufflons Ovis musimon (OM) (176 animals in total) were examined. Determination of categories and numbers of animals in the categories are in Kamler (1999).

The size of total stomach (forestomachs and abomasum) of all species was characterised by its volume and weight of its walls. To prevent autolysis and to reduce wall dilatation after removal of the total stomach from the abdominal cavity, $10 \%$ formalin was applied through its walls. In case of emergency the content of rumen was then completely filled with water injected through the wall so that it was not unnaturally enlarged. To estimate its whole volume, the total stomach was immersed into water and then the displaced volume was measured. Subsequently, the abomasum and the individual parts of forestomachs were separated, the openings closed with clips and the volumes of the individual parts were determined as described above. After removing the contents, the weights of the walls of rumen, reticulum, omasum and abomasum were assessed by weighing with accuracy of $1 \mathrm{~g}$.

The samples were divided into groups by species, 
sex, season, age category and locality of origin for the purpose of evaluation. For these groups the mean values and standard deviations were calculated and subsequently they were tested for true significance of differences using the parametric $t$-test for samples with standard distribution (Kolmogorov-Smirnov test), otherwise by the nonparametric Mann-Whitney U test.

\section{Results}

First, the differences between groups of animals of different ages, sexes and from different seasons and altitudes were tested. In all of the studied species the values of total stomach size were higher in vegetation period than in winter season $(p<0.05)$ (Table 1$)$. The greatest differences were found in the total stomach volume and volume of rumen (15 $-20 \%$ on average). Differences in the volume and weight of reticulum, omasum and abomasum were smaller or not significant (Table 1). Values of volume and weight of the forestomachs and abomasum were expressed to $1 \mathrm{~kg}$ of the total weight of the animal (relative values) (Table 2).

Table 2

Mean values and standard deviations of relative capacity $\left(\mathrm{dm}^{3}\right)$ and weight $(\mathrm{kg})$ of total stomachs of red $(\mathrm{CE})$, fallow (DD) and roe (CC) deer and moufflon (OM) during vegetation and winter period

\begin{tabular}{|c|c|c|c|c|}
\hline Parameter & $\mathrm{CE}$ & DD & $\mathrm{CC}$ & $\mathrm{OM}$ \\
\hline \multicolumn{5}{|c|}{ vegetation period } \\
\hline $\mathrm{N}$ & 28 & 15 & 52 & 12 \\
\hline C. of total stomach & $10.5 \pm 2.7$ & $13.7 \pm 0.8$ & $7.9 \pm 0.59$ & $25.8 \pm 1.12$ \\
\hline C. of rumen & $10.3 \pm 2.9$ & $12.5 \pm 0.8$ & $7.2 \pm 0.60$ & $23.5 \pm 0.93$ \\
\hline W. of total stomach & $2.04 \pm 0.68$ & $2.16 \pm 0.32$ & $2.21 \pm 0.1$ & $3.76 \pm 0.17$ \\
\hline W. of rumen & $1.42 \pm 0.50$ & $1.52 \pm 0.24$ & $1.45 \pm 0.09$ & $2.42 \pm 0.12$ \\
\hline \multicolumn{5}{|c|}{ winter season } \\
\hline $\mathrm{N}$ & 30 & 13 & 13 & 13 \\
\hline C. of total stomach & $8.63 \pm 2.40$ & $12.2 \pm 1.06$ & $6.5 \pm 0.48$ & $21.9 \pm 0.88$ \\
\hline C. of rumen & $7.99 \pm 2.30$ & $11.1 \pm 1.04$ & $6.0 \pm 0.49$ & $19.1 \pm 0.81$ \\
\hline W. of total stomach & $1.59 \pm 0.49$ & $1.75 \pm 0.44$ & $1.70 \pm 0.11$ & $3.46 \pm 0.13$ \\
\hline W. of rumen & $1.03 \pm 0.40$ & $1.12 \pm 0.35$ & $1.08 \pm 0.08$ & $2.16 \pm 0.10$ \\
\hline
\end{tabular}



Fig. 1. Shares of individual parts of total stomach volume of red (CE), fallow (DD) and roe (CC) deer and moufflon $(\mathrm{OM})$ in the winter period.
The influence of sex on the relative size of the total stomach appeared only in roe deer. In vegetation period the female sex had higher values of both relative capacity (by $40 \%$ ) and weight (by 55\%) of the total stomach $(p<0.005)$. In winter season the differences were not tested. In red deer the differences between sexes were significant neither in the vegetation nor in the winter period $(p>0.05)$. In fallow deer and moufflon the differences between sexes were not tested due to small size of samples.

The influence of age on the relative size of the total stomach was proved in $\mathrm{CC}$ and CE. The older animals of both species had higher relative values of the total stomach and rumen volume and weight (by $16-$ $25 \%$ ) in both winter and vegetation periods 


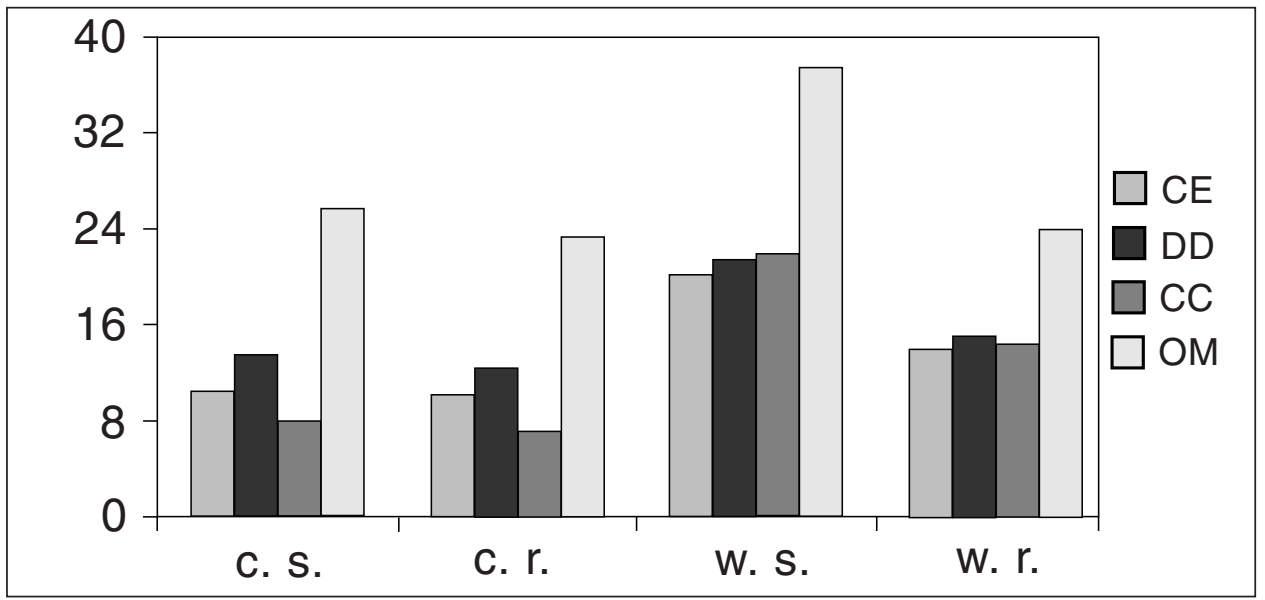

Fig. 2. Relative (per $1 \mathrm{~kg}$ of body weight) capacity $\left(\mathrm{dm}^{3}\right)$ and weight $(\mathrm{kg} \times 10)$ of total stomach and rumen of red (CE), fallow (DD) and roe (CC) deer and moufflon (OM) in vegetation period. Legend: c. s. - capacity of stomach; c. r. - capacity of rumen; w. s. - weight of stomach; w. r. - weight of rumen.

$(p<0.05)$. Age had no influence on the relative size of reticulum, omasum and abomasum $(p>0.05)$. In DD and OM the differences between age categories were not tested due to material deficiency.

The relative size of total stomach and its part was not influenced by altitude. The values of volume and weight of the total stomachs of $\mathrm{CC}$ in both vegetation and winter period were the same in samples from mountain locations and from lower located areas $(p>0.05)$.

Differences between species

Due to the fact that the influences of both sex and age on the relative total stomach size were not significant, the interspecific differences in total stomach size were tested only between winter and vegetation period. The compared groups had even representation of both sexes and age categories of game. Out of the assessed volumes and weights of the total stomach and the separated rumen, reticulum, omasum and abomasum of the studied species, the most significant differences were found in relative volume and weight of the total stomach and rumen. The relatively smallest total stomach volume had CC $(p<0.05)$ and the greatest had OM $(p<0.05)$ in both vegetation and winter periods. The difference between $\mathrm{CE}$ and DD was not significant $(p>0.05)$. Relative weight of the total stomach walls was the smallest in CE, DD and CC and the differences between these species were not significant $(p>0.05)$; significantly higher total stomach weight had OM $(p<0.05)$.

The same share of volume of individual parts in the total stomach volume was found in $\mathrm{CE}, \mathrm{DD}$ and $\mathrm{OM}$ in both vegetation and winter periods. Only CC, in comparison with the other species, had relatively smaller volume of rumen (by $9 \%$ ) and, on the contrary, larger reticulum (by $20-30 \%)(p<0.05)$.

Share of weight of individual parts (walls) in the total stomach weight did not vary significantly among all of the four studied species $(p>0.05)$.

\section{Discussion}

Our results confirm the expected differences in relative size of forestomachs and abomasum of the four studied free-living ruminant species. Characteristics of total stomach found in these species correspond with their classification into morphophysiological feeding 
types according to Hofmann (1989). Differences in total stomach size between vegetation and winter period were found in all of the studied species $(p<0.05)$. They are caused by seasonal changes of food supply (Hofmann 1973) described in similar conditions by Žilinec (1995), Homolka (1995) and others.

Studies comparing the food quality of males and females demonstrated the differences in red deer (Clutton-Brock et al. 1982; Staines et al. 1982 and others), fallow deer (Thirgood 1996) and many other species of free-living ruminants (Pérez-B arbería and Gord on 1998). Some studies have shown higher quality of food in females (Staines et al. 1982; Beier 1987), others in males (Clutton-Brock et al. 1982; Miquelle et al. 1992), sometimes no differences in food quality between sexes were found (Weckerly and Nels on 1990 and others).

In this study the differences in total stomach capacity between sexes were tested. In CC the difference between males and females was detected in vegetation period $(p<0.05)$. Higher values of stomach capacity found in females agreed with the hypothesis that they have higher requirement of nutriments during lactation, but in $\mathrm{CE}$ we found no differences between sexes $(p>0.05)$.

No differences between relative total stomach capacity of animals of different age categories were found. The intensive development of forestomach in ruminants begins with the consumption of roughage (Jelínek 1995). In the material used in this study, differences between absolute sizes of forestomachs of adult animals of different ages existed, but the relative capacity of the stomachs remained the same.

No differences were found in total stomach capacity between animals living in different altitudes $(p>0.05)$. Differences in diet composition in similar environments, described for example by Homolka (1996), had no influence on the total stomach size.

According to our presumption, no differences were found in stomach capacity between $\mathrm{CE}$ and DD $(p>0.05)$, both belonging to intermediate feeders (Hofmann 1989). The smallest stomach of CC corresponds to its feeding type - browser. The biggest stomach, compared to other species, had OM, which corresponds to its classification as a grazer. The differences of total stomach and rumen capacity found in the studied species are in agreement with the knowledge about their diet composition. Roe deer is able to process only the best digestible compounds of food supply and therefore consumes woody species and dicotyledonous plants above all. Red and fallow deer who can utilise also the less easily decomposable food, consume all accessible forage compounds from woody species to grasses. Moufflon is capable of utilising forage with high fibre content and therefore consumes mostly grasses (Heroldová 1988; Homolka 1995, 1996; Jong et al. 1995; Latham et al. 1999 and others). These data support the hypothesis that the species with bigger forestomach capacity consume easily accessible food with lower nutritional value while the species with smaller forestomach capacity select nutritionally more valuable compounds of food supply (Henke et al. 1988).

Comparison of the stomach capacity of selected species confirmed the presumption that the smallest differences in size of the forestomachs are between CE and DD. Also, these species have similar diet composition, which enables their mutual food competition. Due to their similar body size it is possible to presume that in areas with higher density of their populations the food competition between these species is very likely to develop. On the contrary, the competition relations are usually reduced between $\mathrm{CC}$ with significantly smaller forestomach capacity causing its inability to use less easily digestible food, and OM, which prefers grasses due to its stomach adapted to food rich in fibre.

In conclusion: The knowledge of feeding strategy of individual game species can be used to estimate the probability of development of food competition between them and to project a balanced species composition of herbivores in a specific area with regard to their impact on 
vegetation. Seasonal changes of the total stomach size are important part of strategy of wintering ruminants. At this time ruminants have lower food intake and lower activities and this fact must be respected by game managers. Introduction of fallow deer is risky especially when it is brought into environment with red deer due to their equal diet composition. However, fallow deer competes with other herbivores as well and may increase the lack of forage, especially during winter. Moufflon, as a grass and roughage eater, covers his food demands during vegetation period mostly with grasses without major impact on other species. During winter season, when the food supply is limited, and in certain types of environment even in vegetation period, its diet composition becomes similar to that of other ruminants. Moreover, the presence of moufflon increases the impact of herbivores on vegetation during winter.

Simultaneous keeping of red and fallow deer on one site is therefore not desirable and introduction of fallow deer can be recommended only into environments with sufficient food resources. Simultaneous presence of red deer, fallow deer and moufflon is possible purely in localities with abundant food supply.

\section{Rozdíly velikosti předžaludku a slezu u čtyř druhů volně žijících přežvýkavců}

Byl porovnáván relativní objem a hmotnost předžaludku a slezu volně žijících jelenů, daňků, srnců a muflonů. Celkem bylo v letech 1995-1998 vyšetřeno 176 ulovených jedinců. Sledované parametry byly hodnoceny v závislosti na pohlaví, věku, sezóně a lokalitě. Ve vegetačním období byl u všech čtyř sledovaných druhů předžaludek větší, než v zimním období. U srnce se relativní velikost předžaludku lišila u jednotlivých pohlaví a u jelena a srnce byly zjištěny rozdíly mezi věkovými kategoriemi. Velikost předžaludku a slezu se nelišila u zvěře z horského prostředí a níže položených lokalit. Relativní velikost celého žaludku byla největší u muflona a nejmenší u srnce. Rozdíly mezi daňkem a jelenem nebyly průkazné.

\section{Acknowledgements}

We wish to thank Dr. Miloslav Homolka for continuous support during the work on this study and for his critical comments on the manuscript and Ing. Miluše Poláková for her English linguistic improvements. This study was supported by the Grant Agency of the Czech Republic, Grant No. 206/99/D053 and Grant Academy of Sciences of the Czech Republic No. S 6093003.

\section{References}

BEIER, P 1987: Sex-differences in quality of white-tailed deer diets. J Mammal 68: 323-329

CLUTTON-BROCK, TH, GUINNESS, FE, ALBON, SD 1982: Red deer: behavior and ecology of two sexes. University of Chicago Press, Chicago

HANLEY, AT 1982: The nutritional basis for food selection by ungulates. J Range Manage 35: 146-151

HENKE, SE, DEMARAIS, S, PRISTER, JA, 1988: Digestive capacity and diets of white tailed deer and exotic ruminants. J Wildl Manage 52: 595-598

HEROLDOVÁ, M 1988: The diet of moufflon (Ovis musimon) outside the growing period 1983-1984. Folia Zool 37: $309-318$

HOFMANN, RR 1973: The ruminant stomach (Stomach structure and feeding habits of East African game ruminants). E A Monogr Biol, Nairobi $354 \mathrm{p}$.

HOFMANN, RR 1989: Evolutionary steps of ecophysiological adaptation and diversification of ruminants: a comparative view of their digestive system. Oecologia 78: 443-457

HOMOLKA, M 1995: The diet of Cervus elaphus and Capreolus capreolus in deforested areas of the Moravskoslezské Beskydy mountains. Folia Zool 44: 227-236

HOMOLKA, M 1996: Foraging strategy of large herbivores in forest habitats. Folia Zool 45127-136

JELÍNEK, K 1995: Developmental dynamics of the Caprine (Capra aegagrus f. hircus) forestomach in the postnatal period. Acta Vet Brno 64: 49-61

JONG, CB, GILL, RMA, WIEREN, SE, BURLTON, GWE 1995: Diet selection by roe deer Capreolus capreolus in Kielder Forest in relation to plant cover. Forest ecology and management 79: 91-97

KAMLER, J 1999: Infusorial concentration in rumen fluid of red deer, fallow deer, roe deer and moufflon. Acta Vet Brno 68: 247-252 
LATHAM, J, STAINES, BW, GORMAN, ML 1999: Comparative feeding ecology of red deer (Cervus elaphus) and roe deer (Capreolus capreolus) in Scottish plantation forests. J Zool Lond 124: 409-418

MIQUELLE, DG, PEEK, JM, VANBALLENBERGHE, V 1992: Sexual segregation in Alaskan moose. Wildl. Monogr. pp. 1-57

PÉREZ-BARBERÍA, FJ, GORDON, IJ 1998: The influence of sexual dimorphism in body size and mouth morphology on diet selection ond sexual segregation in cervids. Acta Vet Hung 46: 357-367

STAINES, BW, CRISP, JM, PARISH, T 1982: Differences in the quality of food eaten by red deer (Cervus elaphus) stag and hinds in winter. J Appl Ecol 19: 65-77

THIRGOOD, SJ 1996: Ecological factors influencing sexual segregation and group-size in fallow deer (Dama dama). J Zool 239: 783-797

WECKERLY, FQ, NELSON, JP 1990: Age and sex-differences of white-tailed deer diet composition, quality, and calcium. J Wildl Manage 54: 532-538

ŽILINEC, J 1995: Seasonal changes in the nutrition of red deer and roe deer on Polana and Sitno (in Slovak). Folia Venatoria 25: 19-29 